\title{
THE MEANING OF MONEY LAUNDERING IN BUSINESS LIFE AND THE PREVENTION OF IT
}

\section{A. Türkössy}

Faculty of Engineering, University of Szeged, Mars tér 7. 6724, Szeged, Hungary, e-mail: turkaniko@gmail.com

\begin{abstract}
ABSTARCT
Money laundering is the process whereby the proceeds of crime are transformed into ostensibly legitimate money or other assets. The actuality of the subject derives from the Select Committee on the Evaluation of Anti Money Laundering Measures aided by the Financial Action Task Force. Money obtained from certain crimes, such as extortion, drug trafficking, illegal gambling and tax evasion trough off shore companies as "dirty". The reason of the Committee program is to give aides to those countries which wore not FATF members as money laundering is the most profit yielding business on the world with it's 2800 milliard USD turnover. This organization controls Hungary by supervising the law and overall actions giving a so called Progress Report about the achievements.

In aspect of criminal affairs Money laundering includes all activities which achieve to transform the origin of funds coming from criminal activity as well as tax evasion activity into a legalized form. Money laundering as a phenomenon became a global problem in the second half of the 20th century parallel to sudden increase of drug trafficking. In the past few decades money laundering and the chain of criminal activities as underlying offences got into the scope of the leading economic states. Those activities of money laundering maximally exploit the free movement of capital and financial services. In both the economy and political life there is a need for having laws and regulations against money laundering which rigorously regulate the different financial, bank supervisory activities. According to estimations in the nineties three hundred billion dollars were circulating annually across the world in order to be laundered. Nowadays this figure is well over thousand billion dollars.
\end{abstract}

Keywords: money laundering, financial action task, terrorist financing

\section{INTRODUCTION}

Anti-money laundering (AML) is a term mainly used in the financial and legal industries to describe the legal controls that require financial institutions and other regulated entities to prevent or report money laundering activities. Anti-money laundering guidelines came into prominence globally after the September 11, 2001 attacks and the subsequent enactment of the USA PATRIOT Act.

Today, most financial institutions globally, and many non-financial institutions, are required to identify and report transactions of a suspicious nature to the financial intelligence unit in the respective country. For example, a bank must perform due diligence by verifying a customer's identity and monitor transactions for suspicious activity. To do this, many financial institutions utilize the services of special software, and use the services of companies such as C6 to gather information about high risk individuals and organizations. United States federal law for example related to money laundering is implemented under the Bank Secrecy Act as amended by anti-money laundering acts up to the present. Many people have confused Anti-Money Laundering (AML) with Anti-Terrorist Financing (ATF). Under the Bank Secrecy Act of USA, Money Laundering and Terrorist Financing are classified when financial institutions file Suspicious Activity Reports (SAR) to Financial Crimes Enforcement (FinCEN) which is a US government agency. To effectively implement AML and ATF measures, The US government encourages financial institutions to work together for AML and ATF purposes in accordance with Section 314(b) of the USA PATRIOT Act. However, since financial institutions are required by law to protect the privacy of their clients, section 314(b) cooperation has not been generally adopted by financial institutions. To overcome this obstacle, the United Crimes Elimination Network (UCEN) has been established by AML and ATF professionals to achieve this global cooperation goal in compliance with the privacy laws of most countries.

Different countries, depending on the activity, demand different actions [1], [2]. For example; in the US a deposit of US\$10,000 or more requires a CTR (Currency Transaction Report), in Europe it is EUR 15,000, and in Switzerland it is CHF 25,000 in Hungary it is 3,600th HUF requires full identity control. In some countries there is no CTR requirement. Suspicion of ML activity in the US requires the submission of a SAR, while in Switzerland a SAR will only get filed if that activity can be proved. As a result, thousands of SARs are filed daily in the US, while in Switzerland the rate is much lower. 


\section{FATF: FINANCIAL ACTION TASK FORCE AGAINST MONEY LAUNDERING}

Formed in 1989 by the G-7 countries, the Financial Action Task Force on Money Laundering (FATF) is an intergovernmental body whose purpose is to develop and promote an international response to combat money laundering. In October of 2001, FATF expanded its mission to include combating the financing of terrorism. FATF is a policy-making body, which brings together legal, financial and law enforcement experts to achieve national legislation and regulatory AML and CFT reforms. Currently, its membership consists of 31 countries and territories and two regional organizations. In addition, FATF works in collaboration with a number of international bodies and organizations [2.] These entities have observer status with FATF, which does not entitle them to vote, however permits full participation in plenary sessions and working groups. FATF's three primary functions with regard to money laundering are:

i. Monitoring members' progress in implementing anti-money laundering measures

ii. Reviewing and reporting on laundering trends, techniques and countermeasures, and

iii. Promoting the adoption and implementation of FATF anti-money laundering standards global The Financial Action Task Force on Money Laundering (FATF), also known by its French name Groupe d'action financière sur le blanchiment de capitaux (GAFI), is an inter-governmental body founded in 1989 by the G7. The purpose of the FATF is to develop policies to combat money laundering and terrorist financing. The FATF Secretariat is housed at the headquarters of the OECD in Paris. FATF Associate Members include

The FATF currently comprises 34 member jurisdictions and 2 regional organizations, representing most major financial centers in all parts of the globe. - Argentina, Australia ,Austria, Belgium, Brazil, Canada, China, Denmark, European Commission, Finland, France, Germany, Greece, Iceland, India, Ireland, Italy, Japan, Netherlands, Luxembourg, Mexico, New Zealand, Norway, Portugal, Russian Federation, Singapore, South Africa, Spain, Sweden, Switzerland, Turkey, United Kingdom, United States.

The Financial Action Task Force (FATF) is an inter-governmental body whose purpose is the development and promotion of policies, both at national and international levels, to combat money laundering and terrorist financing. The Task Force is therefore a "policy-making body" which works to generate the necessary political will to bring about national legislative and regulatory reforms in these areas.

Since its creation the FATF has spearheaded the effort to adopt and implement measures designed to counter the use of the financial system by criminals. It established a series of Recommendations in 1990, revised in 1996 and in 2003 to ensure that they remain up to date and relevant to the evolving threat of money laundering that set out the basic framework for anti-money laundering efforts and are intended to be of universal application.

The FATF monitors members' progress in implementing necessary measures, reviews money laundering and terrorist financing techniques and counter-measures, and promotes the adoption and implementation of appropriate measures globally. In performing these activities, the FATF collaborates with other international bodies involved in combating money laundering and the financing of terrorism..

\section{HISTORY OF THE FATF}

In response to mounting concern over money laundering, the Financial Action Task Force on Money Laundering (FATF) was established by the G-7 Summit that was held in Paris in 1989 [3]. Recognizing the threat posed to the banking system and to financial institutions, the G-7 Heads of State or Government and President of the European Commission convened the Task Force from the G-7 member States, the European Commission and eight other countries.

The Task Force was given the responsibility of examining money laundering techniques and trends, reviewing the action which had already been taken at a national or international level, and setting out the measures that still needed to be taken to combat money laundering. In April 1990, less than one year after its creation, the FATF issued a report containing a set of Forty Recommendations, which provide a comprehensive plan of action needed to fight against money laundering.

In 2001, the development of standards in the fight against terrorist financing was added to the mission of the FATF. In October 2001 the FATF issued the Eight Special Recommendations to deal with the issue of terrorist financing. The continued evolution of money laundering techniques led the FATF to revise the FATF standards comprehensively in June 2003. In October 2004 the FATF published a Ninth Special Recommendations, further strengthening the agreed international standards for combating money laundering and terrorist financing - the 40+9 Recommendations. 


\section{BACKGROUND ON THE MONEYVAL}

In 2002, the PC-R-EV formally changed its name to MONEYVAL. MONEYVAL was established in September 1997 by the Committee of Ministers of the Council of Europe to conduct self and mutual assessment exercises of the anti-money laundering measures in place in Council of Europe member states, which are not members of the Financial Action Task Force * (FATF). The effort includes encouraging jurisdictions to improve their anti-money laundering measures in keeping with the FATF Forty +9 Recommendations and to enhance international co-operation. Currently 28 Council of Europe member States are evaluated by MONEYVAL. In 2006 the Committee of Ministers accepted the application of the State of Israel to join MONEYVAL's terms of reference and Israel has since been evaluated by MONEYVAL. MONEYVAL also engages in a regular typologies exercise focused on the methods and trends of money laundering activity.

MONEYVAL takes into account the practices and procedures of the FATF in its work. MONEYVAL is a sub-committee of the European Committee on Crime Problems of the Council of Europe (CDPC). Each of its member countries is entitled to appoint three experts to MONEYVAL [4]. These individuals are selected based on their expertise in legal issues related to national and international anti-money laundering instruments, supervision of financial institutions, and law enforcement matters. There are thrice-yearly Plenary meetings of the Committee at which the national experts consider and adopt draft mutual evaluation reports and follow up reports of evaluated members of members. Additionally, the MONEYVAL membership also includes experts from the past and current Presidency of the FATF and four scientific experts appointed by the Secretary General.

When MONEYVAL (then called PC-R-EV) was formed in 1997, a document containing the terms of reference for the Committee was agreed at the same time. The Terms of Reference have since been amended to extend the mandate of the Committee until 31 December 2010. The amended Terms of Reference also permit FATF member countries to participate as observers in the work of the Committee.

\section{ASPECTS FOR EU MEMBER STATES}

The European Union is also active in the formation of institutional system against money laundering [5]. On the basis of the FATF recommendations it has adopted its directives that have to be implemented by the EU member states. In Hungary the Parliament adopted the Act CXXXVI of 2007 on the Prevention and Combating of Money Laundering and Terrorist Financing (AML/CFT Act) that implements the Third EU AML/CFT Directive (Directive 2005/60/EC of the European Parliament and of the Council on the prevention of the use of the financial system for the purpose of money laundering and terrorist financing) into the national legislation. The EU directive 2005/60/EC "on the prevention of the use of the financial system for the purpose of money laundering and terrorist financing" tries to prevent such crime by requiring banks, real estate agents and many more companies to investigate and report usage of cash in excess of $€ 15,000$. The earlier EU directives 91/308/EEC and 2001/97/EC also relate to money laundering. The European Union is currently negotiating a New 4 th Anti - Money Laundering Directive that will change the nature of anti-money laundering compliance across the European Union.

\section{REFERENCES}

[1] Nemzeti Adó és Vámhivatal : nav.gov.hu/criminal_branch_of_NTCA/anti_money_laundering

[2] Act on Prevention of money laundering and terrorism 2007.CXXXVI.

[3] Patric Moulette IMF 2000

[4] http://www.fatf-gafi.org/document

[5] Money Laundering, A New International Law Enforcement Model, Cambridge Studies 2000 